Society since 1930. In 1951 the newly-formed Association of Canadian Geographers began issuing the Canadian Geographer as a quarterly. It also produces a valuable annual roport which lists geographical research publications and statisties relating to geography in Canadian universities. This association now has a membership of more than six hundred of whom half are associate or student members. Its British Columbia Division has beon publishing Occasional Papers since 1960.

The Geographical Branch issues a range of publications including an annual Bibliographical Series and an irregular series of Geographical Papers, both since 1950, the Geographical Bulletin since 1951 and memoirs since 1953 , as well as the Canadian atlases and gazetteers and various coloured maps. The Geographical Bulletin became a quarterly in 1965. The Cahiers de Géographie de Québec have been published by the Institut de Géographie de l'Université Laval since 1952 and the Centre d'Etudes Nordiques has produced a series of Travaux Divers appearing irregularly since 1963. Mention must also be made of The Carlographer which made its début as a twico-yoarly publication during 1964. Although it is published by the Ontario Institute of Chartered Cartographers, it is strongly slanted to the cartographic interests of the geographer. Papers in Canadian periodicals are not necessarily in the same language as the title of the journal. English articles are often supported by a French summary and vice versa.

There are almost limitless possibilities for geography in Canada. Covering an area of 3.75 million square miles, its population is still only 20 million. Much of the territory has yet to be investigated and there are numerous problems in the fields of both physical and human geography awaiting attention. Hand in hand with the opening up of the country there is a growing demand for experts in geographical education, land use assessment, town and country planning, climatology, cartography, pedology, marketing and intelligence work-avenues of activity and careers into which the appropriately trained geographer fits with ease.

\title{
OBITUARIES
}

\section{Prof. N. I. Grashchenkov}

ON October 8, 1965, one of the most outstanding Soviet neurologists and neurophysiologists, Prof. Nikolai Grashchenkov, died at the age of sixty-five at the height of his creative activity.

From the first, Prof. Grashchenkov strove in all his scientific activity to establish the physiological method in neurology. He understood clearly that the extremely subtle experiments which Nature performs by effecting the central and peripheral formations of the nervous system in man considerably enlarge the perspectives of creating real human physiology. Throughout his scientific activity, N. I. Grashchenkov carried these principles into practice. As part of his training, Grashchenkov spent 2 years at the most advanced physiological laboratories of the world at the Universities of Cambridge, New Haven, New York and Boston. When he returned to the Soviet Union, he placed experimental investigations at his offices on a broad footing.

During the Second World War, Prof. Grashchenkov turned his investigations in clinical neurophysiology towards the war effort, and at the same time he became consulting physician at one of the Field Forces. It was there that he formulated the hypothesis of the malfunction of the synaptic structures in the central nervous system being responsible for reversible disorders. He founded the doctrine of functional asynapsy in some pathological conditions of the brain and spinal cord, which still has great theoretical and practical importance.

In his investigations of synaptic processes in the central nervous system, Grashehenkov concentrated his attention on the role of bio- and physico-chemical interrelations in some forms of nervous pathology.

Together with his collaborators he published a large number of books, articles and monographs dealing with the role of the hypothalamus in the neuro-humoralhormonal regulation of brain functions. These investigations were of great importance in the elucidation of the problem of homoeostasis in physiology and in elinical neurology. He showed that laboratory, clinical or physiological examinations alone did not give a reliable indication of the status and functions of healthy or sick organisms and of the work of different organs or physiological systems. These problems could be solved only by means of consistent dynamic study of physiological and biochemical parameters.

One of the features of the investigations carried out at Prof. Grashchenkor's latuoratory was the application of dosed-out functional load, making it possible to find homoeostatic limits and in each case to expose the links most open to injury in the system of homoeostatic forces of the organism. This approach made it possible to put into practice a number of new therapeutic methods in the treatment of some forms of hypothalamic pathology.

Grashchenkov paid much attention to the physiological analysis of traumatic injuries of the brain and to the problem of muscular diseases, particularly myasthenia. The most important problems of neurophysiology, such as the questions of function localization in the brain, of sleep and arousal, behaviour and the orientating reaction, lay within the range of his interests. Grashchenkov's works on virus encephalitis are also well known, and his early results on this subject still retain their value and scientific significance.

Grashehenkov combined his scientific and pedagogical work with great organizational activity in the field of public health in the U.S.S.R. $\mathrm{He}$ hold a number of responsible posts in the Ministry of Public Health, and for a number of years he was the president of the Byelorussian Academy of Sciences. In recent years, also, he was one of the leaders of the Physiological Department of the U.S.S.R. Acaderny of Sciences.

Grashchenkov's life shows the possibilities open to people of talent in Soviet society. The son of a peasant, a village cowhord, he took part in the Civil War and became one of the leading scientists not only in home but in world medicine. He was, for some years, assistant directorgencral of the World Health Organization; he repeatedly represented the U.S.S.R. in different international organizations, and participated in many international scientific symposia. In the person of Nikolai Grashchenkov, Soviet medicine has lost one of its most gifted and versatile ropresentatives.

G. KASSIL

\section{Dr. I. L. Chaikoff}

Dr. Israel Lyon Chatroff died on January 25, 1966 , in Berkeley, California. $\mathrm{He}$ was born in London on July 2, 1902, and he grew up in Toronto. He graduated from the University of Toronto in 1924 and immediately embarked on his career of research in physiology, which started in association with the late Prof. J. J. R. Macleod, in the department where insulin had recently been dis. covered by Banting and Best. The impact of the discovery had many effects; one of these was to shape 
the lives of contemporary young research workers in the medical sciences. One of the most distinguished of these was I. L. Chaikoff. He received the degrees of Ph.D. in 1927 and M.D. in 1930 from the University of Toronto, after which he joined the faculty of the University of California at Berkeley. Here he became a full professor in 1942. His laboratory maintained an unbroken flow of eminent contributions to biochemical endocrinology and metabolism. Many of his students continued their work in these fields as prominent members of the faculties of other universities.

Chaikoff was an originator in metabolic research, with the broadest of interests in biochemistry, medicine and nutrition. $\mathrm{H}_{e}$ was one of the first to introduce radioisotopes in biology and medicine, and he pioneered with iodine-131, phosphorus-32 and carbon-14 in research on the thyroid, the pancreas, and the liver. For years he investigated the biochemical changes following experimental pancreatectomy, especially with regard to the aetiology of fatty infiltration of the liver. He made numerous investigations in arteriosclerosis, phospholipid metabolism, cholesterol biosynthesis (including the role of squalene as a precursor), lipogenesis, the role of insulin in intermediary metabolism, fatty acid oxidation, carbohydrate metabolism, the action of oestrogens, anterior pituitary hormones, adrenal steroids, and other fields involved with the function of the body.

$\mathrm{He}$ shunned publicity and public appearances, preferring to devote himself to his laboratory, to the teaching and training of students, and to the encouragement of his large staff of scientific associates and collaborators, among whom he inspired many loyal friendships. $\mathrm{He}$ objected strongly to any form of pretentiousness and he had wide literary interests. He was a man of the highest standards in research and scientific writing and he was keenly conscious of the history and progress of the biological sciences. Ho was a prolific contributor to the leading scientific journals in his field, with a list of more than 400 publications in them. He held a Guggenheim fellowship in 1941-42, and a Miller research professorship during 1963-65. He was a Harvey lecturer in 1952, he received the Medal of the Endocrine Society of the United States in 1958 , and he was faculty research lecturer at the University of California in 1958. He was married in 1949 to Isabelle Rawls, who survives him.

T. H. JUKES

\section{NEWS and VIEWS}

\section{The Royal Society of Edinburgh}

Sir Lawrence Bragg has accepted the invitation of the Royal Society of Edinburgh to deliver the James Scott Lecture, 1966 , at the Society's ordinary meeting on March 6, 1967. The Keith Prize for the period 1963-65 has been awarded to Dr. Reinhold Fürth, formerly reader in theoretical physics, Birkbeck College, University of London, for his paper on the statistical thermodynamics of liquids published in the Proceedings of the Society during the period of the award and in recognition of his many valuable contributions in the same field.

\section{Geology in the University of Cambridge :}

Prof. O. M. B. Bulman, F.R.S.

Prof. O. M. B. BuLman resigns from the Woodwardian chair of geology in the University of Cambridge in October; the chair is the oldest geological endowment in Great Britain. Having been successively University demonstrator in geology (1931-34), lecturer in palaeozoology (1934-44), and reader in palaeozoology (1944-53), he was elected to the chair in 1955. He had entered the University of Cambridge as an 1851 Exhibition Senior Student at Sidney Sussex College in 1926 following Ph.D. studies at the Imperial College of Science and Technology under Prof. W. W. Watts, and he returned to Cambridge in 1931 after holding teaching appointments in zoology and geology at Imperial College. Throughout his researches, Prof. Bulman has been predominantly a student of the Graptolithina, a group of fossils extensively used in classifying the Ordovician and Silurian strata. Ho has applied ingenious techniques and gifted powers of illustration to the better understanding of the morphology and evolutionary paths of these fossils. $\mathrm{He}$ and his research students have given remarkable impetus to studies of the group and of its occurrences in various parts of the world. Prof. Bulman has devoted much time to benefit the activities of scientific organizations and has held the office of president of Section C (Geology) of the British Association for the Advancement of Science (1959), the Palaeontological Association (1960-62) and the Geological Society (1962-64). In addition, for more than thirty years he has been a co-editor of the Geological
Magazine. He is at present a member of the Natural Environment Research Council's Geology and Geophysics Committee and a Trustee of the British Museum (Natural History). At Cambridge he has developed a more diversified and adequately accommodated research school and has recently taken a prominent part in the reorganization of the Natural Sciences Tripos and postgraduate studies there.

Prof. H. B. Whittington

Prof. H. B. Whitrington, who will succed Prof. O. M. B. Bulman in October as Woodwardian professor of geology in the University of Cambridge, will take up that appointment with a record of world experience more varied than that of any previous occupant. A graduate, Ph.D. and D.Sc. of Birmingham, he went to Yale as a Commonwealth Fellow in 1938 and in 1940 moved to Rangoon to teach at Judson College. During the Second World War, he became attached to an ambulance unit in Burma, whence he proceeded to Ginling College, in Chengtu. In 1945 he returned to Birmingham, but the invitation which he accepted in 1949 to go to Harvard University as a visiting lecturer was rapidly turned into the offer of a more permanent appointment and for years he has been professor of geology at Harvard and curator of invertebrate palaeontology in the Museum of Comparative Zoology. His copious list of publications includes a worthy number relating to the stratigraphy of the British Isles and America and even one or two on the physiology of Szechuan, but it is as a palaeontologist, and especially as an expert on the trilobites, that he has achieved an international reputation. In 1955 he became secretary of the Palaeontological Society of America and he has just completed his term as president of that body. The Geological Society of London awarded him the Bigsby Medal in 1957. It is a testimony to his international reputation that he has been asked by the Geological Survey of Canada to direct excavations in the Middle Cambrian Burgess Shales of British Columbia which revealed to Walcott so much that was previously unknown and unsuspected in the animal world. Continuation of this direction after next summer will presumably be from Cambridge. 